Supporting Information

\title{
Separation of semiconducting from metallic carbon nanotubes by selective functionalization with azomethine ylides
}

\author{
Cécilia Ménard-Moyon, Nicolas Izard, Eric Doris* and Charles Mioskowski*
}

\section{General methods}

Purified SWNTs were purchased from Carbon Nanotechnologies Inc. (Houston, TX) and used without further treatment. Trimethylamine $N$-oxide, 3-chloroperbenzoic acid ( $m$-CPBA) and lithium diisopropylamine (LDA) were purchased from Aldrich.

\section{Raman Spectroscopy}

Raman spectra were measured on a dispersive Jobin-Yvon T64000 spectrometer using 514.5 and $647.1 \mathrm{~nm}$ line of an $\mathrm{Ar} / \mathrm{Kr}$ laser, and on a FT/Bruker RFS 100 using the fundamental laser line of a Nd:YAG laser at $1064 \mathrm{~nm}$. The laser power was maintained below $100 \mathrm{~W} / \mathrm{cm}^{2}$ to prevent the heating of the sample.

\section{UV-Vis-nIR}

The spectra in the UV-vis-nIR range were obtained using a Perkin-Elmer UV-Vis-nIR Lambda 900 spectrometer.

\section{Thermogravimetric Analysis (TGA)}

Analyses were performed with a TGA 92 apparatus (SETARAM). Experiments were carried out under argon. Samples were heated at $5^{\circ} \mathrm{C} / \mathrm{min}$ from $25^{\circ} \mathrm{C}$ to $800^{\circ} \mathrm{C}$ and heated at $800{ }^{\circ} \mathrm{C}$ for $30 \mathrm{~min}$.

\section{X-Ray Photoelectron Spectroscopy (XPS)}

XPS spectra were recorded on a Vacuum Generator ESCALAB 210 spectrometer, using an A1 $\mathrm{K} \alpha$ source $(20 \mathrm{~mA}, 15 \mathrm{kV})$ monochromatized at $1486.6 \mathrm{eV}$ and equipped with a hemispherical electron energy analyser. The operating pressure in the analysis chamber was set below $10^{-10}$ mbar $\left(1.3310^{-8} \mathrm{~Pa}\right)$. The instrument calibration was performed by setting $\mathrm{Ag}$ $3 \mathrm{~d}^{5 / 2}$ binding energy at $368.70 \mathrm{eV}$. The $\mathrm{N} 1 \mathrm{~s}$ core level was recorded at fixed pass energy of $20 \mathrm{eV}$ and a take-off angle of $90^{\circ}$ with respect to the sample plane. In these conditions the resolution of the spectrometer, referring to the $\mathrm{Ag} 3 \mathrm{~d}^{5 / 2}$, was $0.8 \mathrm{eV}$.

\section{NMR spectroscopy}

Spectra were recorded on a BRUKER AC 300 spectrometer. Chemical shifts are given in ppm relative to chloroform $\left(7.25 \mathrm{ppm},{ }^{1} \mathrm{H}\right.$ and $\left.77 \mathrm{ppm},{ }^{13} \mathrm{C}\right)$. The resonance multiplicity is indicated as s (singlet), d (doublet), t (triplet), m (multiplet).

\section{General procedure for the synthesis of $N$-oxides (2) and (3)}

To a solution of the tertiary amine ( 1 equiv) in $\mathrm{CH}_{2} \mathrm{Cl}_{2}$ at $0{ }^{\circ} \mathrm{C}$ was added $m$-CPBA (1.1 equiv). The reaction mixture was stirred at $0{ }^{\circ} \mathrm{C}$ for $1 \mathrm{~h}$ and at room temperature for an additional $1 \mathrm{~h}$. The solution was concentrated under reduced pressure and the residue was purified by chromatography over silica $\left(\mathrm{CH}_{3} \mathrm{OH} / \mathrm{CH}_{2} \mathrm{Cl}_{2}: 1 / 9\right)$ to give the desired $N$-oxide. 
- $\mathrm{N}, \mathrm{N}$-Dimethyl-4-(pyren-3-yl)butan-1-amine $\mathrm{N}$-oxide (2): Formula: $\mathrm{C}_{22} \mathrm{H}_{23} \mathrm{NO}$. MW: 317. Beige solid. Yield: $86 \% .{ }^{1} \mathrm{H}$ NMR $\left(\mathrm{CDCl}_{3}, 300 \mathrm{MHz}\right): \delta 1.88(\mathrm{~m}, 2 \mathrm{H}), 2.05(\mathrm{~m}, 2 \mathrm{H}), 3.11$ (s, $6 \mathrm{H}), 3.23(\mathrm{~m}, 2 \mathrm{H}), 3.39$ (t, $\left.{ }^{3} J=7.6 \mathrm{~Hz}, 2 \mathrm{H}\right), 7.83\left(\mathrm{~d},{ }^{3} J=7.9 \mathrm{~Hz}, 1 \mathrm{H}\right), 7.96\left(\mathrm{~d},{ }^{3} J=8.0 \mathrm{~Hz}\right.$, $1 \mathrm{H}), 8.01(\mathrm{~m}, 2 \mathrm{H}), 8.09\left(\mathrm{~d},{ }^{3} J=7.9 \mathrm{~Hz}, 1 \mathrm{H}\right), 8.15(\mathrm{~m}, 3 \mathrm{H}), 8.21\left(\mathrm{~d},{ }^{3} J=9.8 \mathrm{~Hz}, 1 \mathrm{H}\right) .{ }^{13} \mathrm{C}$ NMR $\left(\mathrm{CDCl}_{3}, 75 \mathrm{MHz}\right): \delta 23.7,28.7,33.1,58.7,71.3,123.0,124.7,124.9,125.0,125.8$, $126.7,127.2,127.4,128.5,129.9,130.8,131.3,135.6$. IR $(\mathrm{KBr}): v\left(\mathrm{~cm}^{-1}\right)=3222,3037,2949$, 2864, 1457, 845. MS (ESI / TOF): $m / z=318\left(100,[\mathrm{M}+\mathrm{H}]^{+}\right), 340\left(19,[\mathrm{M}+\mathrm{Na}]^{+}\right), 635(39$, $\left.[2 \mathrm{M}+\mathrm{H}]^{+}\right)$. HRMS (ESI / TOF) calcd for $\mathrm{C}_{22} \mathrm{H}_{23} \mathrm{NNaO} 340.1677$, found 340.1678.

- 3-(Anthracen-10-yl)- $N, N$-dimethylpropan-1-amine $N$-oxide (3): Formula: $\mathrm{C}_{19} \mathrm{H}_{21} \mathrm{NO}$. $\mathrm{MW}$ : 279. Yellow solid (m.p.: $\left.151-152{ }^{\circ} \mathrm{C}\right)$. Yield: $91 \%$. ${ }^{1} \mathrm{H}$ NMR $\left(\mathrm{CDCl}_{3}, 300 \mathrm{MHz}\right): \delta 2.46(\mathrm{~m}, 2$ H), $3.11(\mathrm{~s}, 6 \mathrm{H}), 3.43\left(\mathrm{t},{ }^{3} J=8.2 \mathrm{~Hz}, 2 \mathrm{H}\right), 3.74\left(\mathrm{t},{ }^{3} J=7.6 \mathrm{~Hz}, 2 \mathrm{H}\right), 7.50(\mathrm{~m}, 4 \mathrm{H}), 8.02(\mathrm{~d}$, $\left.{ }^{3} J=8.0 \mathrm{~Hz}, 2 \mathrm{H}\right), 8.24\left(\mathrm{~d},{ }^{3} J=8.8 \mathrm{~Hz}, 2 \mathrm{H}\right), 8.38(\mathrm{~s}, 1 \mathrm{H}) .{ }^{13} \mathrm{C} \mathrm{NMR}\left(\mathrm{CDCl}_{3}, 75 \mathrm{MHz}\right): \delta$ 24.5, 25.1, 58.7, 71.0, 123.7, 124.8, 125.9, 126.3, 129.2, 129.4, 131.4, 132.4. IR (KBr): v (cm ${ }^{-}$ $\left.{ }^{1}\right)=3386,3051,2959,1664,1626,1449,885,736$. MS (ESI / TOF $): m / z=280(100,[\mathrm{M}+$ $\left.\mathrm{H}]^{+}\right), 302\left(40,[\mathrm{M}+\mathrm{Na}]^{+}\right), 559\left(75,[2 \mathrm{M}+\mathrm{H}]^{+}\right)$. HRMS (ESI / TOF) calcd for $\mathrm{C}_{19} \mathrm{H}_{21} \mathrm{NNaO}$ 302.1521 , found 302.1546 .

\section{$\underline{\text { Preparation of functionalized SWNTs 4, } 5 \text { and } 6}$}

\section{- Preparation of functionalized SWNTs 4}

A mixture of SWNTs (20 mg, $1.67 \mathrm{mmol}$ of carbon, 1 equiv) and trimethylamine $N$-oxide 1 (500 mg, 4 equiv of carbon) in $15 \mathrm{~mL}$ of THF was sonicated for $3 \mathrm{~min}$ using an ultrasonic probe (Branson Sonifier 450, $60 \mathrm{~W}, 20 \mathrm{kHz}$ ). The flask was air evacuated and backfilled with $\mathrm{N}_{2}$ three times and kept under $\mathrm{N}_{2}$. The heterogeneous mixture was heated at $65^{\circ} \mathrm{C}$ and a LDA solution (1.8 M in THF/heptane/ethylbenzene, $7.8 \mathrm{~mL}, 8.2$ equiv) was added dropwise over a period of $1 \mathrm{~h}$. The reaction was heated to $65{ }^{\circ} \mathrm{C}$ for $14 \mathrm{~h}$ and allowed to cool to $0{ }^{\circ} \mathrm{C}$. Methanol $(5 \mathrm{~mL})$ was then added and the reaction mixture was centrifuged at $9000 \mathrm{rpm}$ for 5 min. The supernatant was discarded and the residue was dispersed in THF for 5 min using an ultrasonic bath (Branson 5210, $19 \mathrm{~W}, 47 \mathrm{kHz}$ ). The mixture was centrifuged $(9000 \mathrm{rpm}, 5$ $\mathrm{min}$ ) and the supernatant was discarded. The same sequence was repeated thrice using DMF, dichloromethane and finally diethyl ether as solvents. Functionalized SWNTs (4) were dried under vacuum overnight. At this stage, Raman spectroscopy indicated an increase in the $\mathrm{I}_{\mathrm{D}} / \mathrm{I}_{\mathrm{G}}$ ratio by a factor of 2.4. The overall procedure was repeated twice to enhance the degree of functionalization. Raman spectroscopy after the three sequences of functionalization showed an increase in the $\mathrm{I}_{\mathrm{D}} / \mathrm{I}_{\mathrm{G}}$ ratio by a factor 5.1. Control experiments were run without trimethylamine $N$-oxide, i.e. carbon nanotubes reacted with LDA only. These experiments indicated no reactivity of carbon nanotubes towards LDA.

- Preparation of functionalized SWNTs 5 and 6: A typical procedure is given for the preparation of $\mathbf{5}$.

Step 1: pre-organization of the N-oxide on the nanotube surface.

SWNTs (10.2 mg, $0.85 \mathrm{mmol}$ of carbon, 1 equiv) and $1 \mathrm{mg}$ of pyrenyl- $N$-oxide $2(10 \%$ by weight) were suspended for $5 \mathrm{~min}$ in $8.5 \mathrm{~mL}$ of $\mathrm{MeOH}$ using an ultrasonic probe $(60 \mathrm{~W}, 20$ $\mathrm{kHz})$. The mixture was further dispersed using an ultrasonic bath $(19 \mathrm{~W}, 47 \mathrm{kHz})$ for $1 \mathrm{~h}$. The suspension was then vigorously stirred for $14 \mathrm{~h}$. After centrifugation $(9000 \mathrm{rpm}, 5 \mathrm{~min})$, the 
residue was dispersed in methanol $(19 \mathrm{~W}, 47 \mathrm{kHz}, 30 \mathrm{~min})$ and centrifuged again at $9000 \mathrm{rpm}$ for $5 \mathrm{~min}$. The same sequence was repeated until no significant amount of pyrenyl- $N$-oxide (2) was detected in the supernatant by UV/Vis spectroscopy. The pre-organized $N$-oxide / SWNTs were dried under vacuum overnight.

Step 2: covalent functionalization of the nanotubes.

Under $\mathrm{N}_{2}$, pre-organized $N$-oxide / SWNTs were placed in a flame dried flask. LDA (1.8 M in THF/heptane/ethylbenzene; $1.5 \mathrm{~mL}, 3.2$ equiv) was then added slowly at room temperature. The heterogeneous mixture was dispersed in an ultrasonic bath $(19 \mathrm{~W}, 47 \mathrm{kHz})$ for $1 \mathrm{~h}$ and stirred vigorously at $\mathrm{rt}$ for $14 \mathrm{~h}$. Methanol $(1 \mathrm{~mL})$ was then added and the reaction mixture was centrifuged at $9000 \mathrm{rpm}$ for $5 \mathrm{~min}$. The supernatant was discarded and the residue was dispersed in THF for 5 min using an ultrasonic bath $(19 \mathrm{~W}, 47 \mathrm{kHz})$. The mixture was centrifuged again $(9000 \mathrm{rpm}, 5 \mathrm{~min})$ and the supernatant was discarded. The same sequence was repeated four times using DMF, methanol, dichloromethane and diethyl ether as solvents. Functionalized SWNTs 5 were dried under vacuum overnight.

The overall procedure was repeated twice to enhance the degree of functionalization. 